\title{
Retraction to using a deep recurrent neural network with EEG signal to detect Parkinson's disease
}

\author{
Shixiao Xu ${ }^{1}$, Zhihua Wang ${ }^{2}$, Jutao Sun ${ }^{1}$, Zhiqiang Zhang ${ }^{1}$, Zhaoyun Wu ${ }^{1}$, Tiezhao Yang ${ }^{1}$, Gang Xue ${ }^{1}$, \\ Chuance Cheng ${ }^{1}$ \\ ${ }^{1}$ College of Tobacco Science, Henan Agricultural University, Scientific Observation and Experiment Station of Henan, Ministry of Agriculture, \\ Zhengzhou, China; ${ }^{2}$ Department of Respiratory Medicine, Henan Provincial People's Hospital, People's Hospital of Zhengzhou University, \\ Zhengzhou, China \\ Correspondence to: Gang Xue; Chuance Cheng. College of Tobacco Science, Henan Agricultural University, Scientific Observation and Experiment \\ Station of Henan, Ministry of Agriculture, Zhengzhou, China. Email: xuegang@henau.edu.cn; ccc@henau.edu.cn.
}

Submitted Jul 12, 2021. Accepted for publication Jul 22, 2021.

doi: $10.21037 /$ atm-2021-25

View this article at: https://dx.doi.org/10.21037/atm-2021-25

Retraction to: Ann Transl Med 2020;8:874

The article "Using a deep recurrent neural network with EEG signal to detect Parkinson's disease" (doi: 10.21037/atm-205100) published in the Volume 8 No. 14 (July 2020) issue of Annals of Translational Medicine has been retracted due to terrible mistakes found in the article (1). We apologize for the mistakes due to the scientific negligence.

\section{Footnote}

Conflicts of Interest: All authors have completed the ICMJE uniform disclosure form (available at http://dx.doi.org/10.21037/ atm-2021-25). The authors have no conflicts of interest to declare.

Ethical Statement: The authors are accountable for all aspects of the work in ensuring that questions related to the accuracy or integrity of any part of the work are appropriately investigated and resolved.

Open Access Statement: This is an Open Access article distributed in accordance with the Creative Commons AttributionNonCommercial-NoDerivs 4.0 International License (CC BY-NC-ND 4.0), which permits the non-commercial replication and distribution of the article with the strict proviso that no changes or edits are made and the original work is properly cited (including links to both the formal publication through the relevant DOI and the license). See: https://creativecommons.org/ licenses/by-nc-nd/4.0/.

\section{References}

1. Xu S, Wang Z, Sun J, et al. Using a deep recurrent neural network with EEG signal to detect Parkinson's disease. Ann Transl Med 2020;8:874.

Cite this article as: $\mathrm{Xu} \mathrm{S}$, Wang Z, Sun J, Zhang Z, Wu Z, Yang T, Xue G, Cheng C. Retraction to using a deep recurrent neural network with EEG signal to detect Parkinson's disease. Ann Transl Med 2021;9(17):1396. doi: 10.21037/atm-2021-25 